\title{
THE ROLE OF PUBLIC WORK DEPARTMENT ON THE NETWORK SYSTEM IN PERAK DURING BRITISH COLONIAL ERA, 1874-1941
}

\author{
Bipin A/L Babulal ${ }^{1}$ \\ Postgraduates, History Department, \\ Faculty of Human Science, Universiti Pendidikan Sultan Idris \\ (Email: bipinbab@swiftlogistics.com.my) \\ Khairi Ariffin ${ }^{2}$ \\ Assoc. Professor, History Department, \\ Faculty of Human Science, Universiti Pendidikan Sultan Idris \\ (Email: khairi.ariffin@fsk.upsi.edu.my)
}

Accepted date: $23-04-2019$

Published date: 08-07-2019

To cite this document: Babulal, B., \& Ariffin, K. (2019). The Role of Public Work Department on The Network System in Perak during British Colonial Era, 1874-1941. International Journal of Modern Trends in Social Sciences, 2(8), 141-148.

DOI: $10.35631 /$ IJMTSS.280014

\begin{abstract}
The Public Work Department had very important role in the urbanization process in the state of Perak. It was founded in 1872 and the new organization was introduced. The role and involvement of British officers were becoming wider to meet the need in administrative and professional field such as engineering and architecture. The research was carried out by using qualitative methods of collecting the data and information on the role of Public Work Department in the networking system development in the state of Perak. The approaches of document analysis, such as the Federated Malay Stated Government Gazette, Federated Malay States Annual Report of Railways and Perak Secretariat, which obtained from National Archived of Malaysia has been emphasized in collecting the data. The writing and research on Perak development also been referred to strengthening the finding of the study. The finding shows that there were various plans and development, implementation was carried out after the establishment of Public Work Department in Perak. The plan and implementation involve the matters relating to the construction, infrastructure facilities of railways connection and roads. Among them was the construction of the first railway link which connects Taiping and Port Weld. The construction of the railway network was increasing throughout the state until 1930's. Therefore, the Public Works Department has played a major role in ensuring that the implementation of the communication system is well structured and successful.
\end{abstract}

Keywords: Urbanization, Administrative, Development, Infrastructure

\section{Introduction}

The new administration that implemented by the British colonial in the Malay states, especially in Perak has been the trigger for the better economic growth. Among the factors that promote economic growth in Perak where the transformation of the network system 
which consist of a railway network system and the road. In fact, since 1874 the economic policy set by the British colonial administrators has led to the ease of communication networks. The exclusion provision of the road and railway construction has been provided. According to Sir Frank Swettenham in his note that emphasizes the importance of the communication system:

"In the administration of a Malay State, revenue and prosperity follow the liberal, but prudently directed expenditure of public fund, especially when they are invested in high class roads in railways, telegraph, water-works and everything likely to encourage trade and private enterprise. (Swettenham F.A., 1894)

Prior to the establishment of the Public Works Department, the position of the chief engineer was introduced and the post was held by Major John Frederick Adolphus McNair in Singapore in 1858. In 1872, the Public Works Department was established which was also led by Major J.F.A. McNair. The Public Work Department was basically established to manage the construction works such as roads, railways, buildings and infrastructure facilities. After several years, the role of the department has expanded. The main tasks of this department were managing the construction of roads, bridges, buildings and water supply. (Perak Secretariat 439/1948, 1947) When state development was in the early stages in the late 1890s, the engineers assigned in the Department of Public Work Department consisted of English people who were accountable in monitoring and supervision in every work undertaken. This is to ensure professional technical standards were complied and all the provisions by the colonial government for development work was well spent.

The department has a relatively large number of staff members which was about 350 people in 1946. (Perak Secretariat 439/1948, 1947). The involvement of the Malays in the Public Work Department was also encouraged during the British rule. (Proceeding of Federated Malay State, 1933). The employment opportunities of the Malay community before the British colonial era were said to be at an unsatisfactory level, even though the country rich in various sources. After the construction of the railway network which was carried out by the Public Works Department, the Malays has been involved as laborers in the construction sector. Construction work of railways and roads has become one of the sources of income among the Malays and their involvement as the construction worker was quite high. (Proceeding of Federated Malay State, 1933).

In 1933, the district administration of Public Work Department was restructured. (Annual Report on Social and Economic Progress of People of Perak, 1933). This restructuring was done for the benefit of the economy of the state of Perak. At the same time it aims to provide adequate training to the Malay Administrative Officers in the Public Works Department. Among the personnel that involved in the restructuring were in the districts of Kuala Kangsar, Hilir Perak, Batang Padang, Hulu Perak, Krian, secretary and chairman, Sanitary Board, and assistant district officer of Sitiawan. These positions involved are reduced and combined. District Officers of Batang Padang, Hulu Perak and Krian were placed under the supervision of the District Officers of Perak, Kuala Kangsar and Larut. The appointment of Assistant District Officer of Tapah was removed from Class The appointment of Assistant District Officer of Tapah was removed from Class 5 of the Malayan Civil Services and was transferred to the Malay Administrative Services of the Malayan Civil Services and was transferred to the Malay Administrative Services. The result of this arrangement has improved the performance of the officer in a very satisfying work. 
The reorganization of organizational administration is seen as one of the administrative system development processes in order to be more well organized in order to develop more experienced Malay officers through the training given. At the same time, the British also said the restructuring was for the benefit of the state and the colonial economy. It also demonstrates the British's efforts in bringing in engineering and its influence in administrative management to be adopted in local government.

\section{Problem Statement}

The British administration in the state of Perak, especially after 1874, had affected the development of the jurisdiction of government official departments, especially in the development of the state of Perak. The increase in the tin mining and rubber plantation sectors led to the construction of railway and roadways to facilitate the transport of tin and rubber. The Public Works Department, which was formally established in 1872, has a major and important role in the implementation of the railway and railroad network development in Perak. The development of this communication network has become one of the major factors that led to the development of the Perak state economy as its existence was a profitable investment for the British colonial administration as well as the people of Perak.

\section{Objective}

i. To study the role of The Public Work Department in the development of networking system and transportation in Perak.

ii. To analyze the impact of road construction and transportation in economic activity in Perak.

iii. Evaluating the importances of networking and the transportation system in Perak.

\section{Research Question}

i. What is the role of Public Work Department in terms of networking and transportation system development in Perak?

ii. What is the impact of networking and transportation systems towards the state's economy?

iii. How far are the importances of networking and the road system in Perak?

\section{Theoretical Framework}
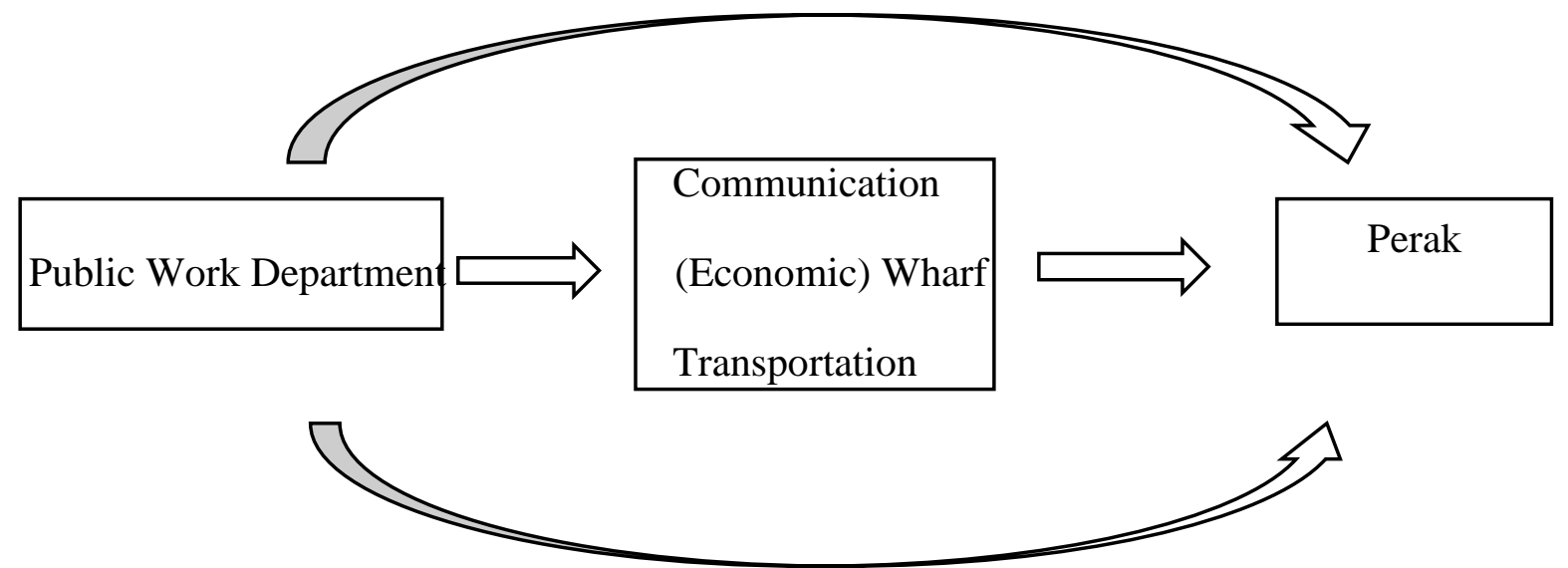
Theoretical framework in this study emphasizes the role played by the Public Work Department during the British colonial era as an effort to develop the economy of the state of Perak. Two important factors in the development of transportation facilities are the provision of road and railway facilities as well as the development of the wharf system. All the important items in this study, which consists of the role of the Public Works Department, Road and Railways Facilities, and the British colonial administration was assessed and reviewed based on primary and secondary sources available at the National Archives and Public Library in Malaysia either at public universities or at the National Library.

\section{Research Scope}

This study focuses on the role of the Public Works Department in the state of Perak during the British colonial era since 1874. This study discusses the role of the Public Works Department until 1941 because of the Japanese invasion caused the British colonial administration to leave Malaya. The study is focusing on the state of Perak by emphasizing the issues of road, railways, and wharf facilities.

\section{Literature Review}

The development of the British colonial era was closely related to the role of the Public Works Department. According to Moo Hoi Ping et al (2018) in his study entitled The Role of Public Department in the Development and Administration of Waterwork in Kuala Lumpur 1900-1941 emphasized that the development of the irrigation system in Kuala Lumpur from 1900 until 1941 was due to the planning and implementation of drainage by the Public Works Department or when it was known as the Public Work Department. The study illustrates the role of the Public Work Department during the time of the British administration not only focusing on the development of the communication system, but also responsible for the implementation of the water drainage system to supply clean water to the locals. However, this study focuses more on the development in the town of Kuala Lumpur based on the role of the Public Works Department in efforts to improve the irrigation system in the city. In addition, the Public Works Department's role in the network system in Kuala Lumpur is described in general and not given much emphasis. The criticism and information on Moo Hoi Ping's writing are evident in portraying the importance of the Public Works Department in Kuala Lumpur town development. It also helps to illustrate the general role of the Public Works Department during the British colonial administration.

Khoo Salma Nasution et al (2005) in her writing emphasized on the developments taking place in the district of Kinta Valley, Perak. Starting with the early history of the Kinta Valley, the author describes in detail the history and development of 15 villages in the Kinta Valley region and most of the districts are associated with mining activities which contributed to the modern urban growth. This writing also mention the important role of Public Work Department as the important government agency that contributes to the development of the Kinta Valley district. This writing also are related to impotances of network that Kinta Valley district towards the urban development.

Li Dun Jen (1982) in his writing relates the political, economic and British colonial administration in Malaya before the Second World War. This writing is not only focused on British colonial occupation in the State of Perak but also highlighted the British influence on trade, population, energy workers, commercial agriculture and tin mining. Li Dun Jen also mention on the growing population of Chinese and Indian immigrants in the last quarter of the 19th century. This writing does not focus on economic analytics only in the state of Perak but support in obtaining an overview of the economic development during the British colonial period in Malaya. 
Amarjit Kaur (1980) in her study emphasizes that the development of tin mining and rubber companies were in large scale which parallel with the development of communication networks of road and railways. In fact, at one level there is competition between the use of road and rail linkage routes that have contributed to the improvement of new railway service upgrades and reduced transportation costs. The description of the involvement of the Public Works Department in the construction of railway and road was generally written and not focusing on development in the state of Perak. However, this study illustrates that the developed system has played an important role in contributing to the economic development of the state of Perak.

While R.S.Nathan (1970) in his writing also emphasized the importance of the railway system or the road that had been developed by the Public Works Department but focused on Batang Padang. In fact, agricultural and mining activities in Batang Padang are difficult to develop without the development of roads and railway network facilities. R. S. Nathan had mentioned that the Public Work Department was supervising the construction of roads and also responsible for the construction of bridge and public building. In Tapah, there was a roofed wooden bridge was constructed over the Batang Padang River in 1892. The explanation shows that the R. S. Nathan written focused the role of Public Work Department in Batang Padang district only.

\section{Research Methodology}

The study was carried out entirely using qualitative methods. The approaches of document analysis, such as the Federated Malay Stated Government Gazette, Federated Malay States Annual Report on Railways, Perak Secretariat and Public Work Department Annual Report, which obtained from National Archived of Malaysia has been emphasized in collecting the data. Secondary reference sources such as books and writings relating to the construction of roads and railway networks in Perak and the Federated Malay States during the British colonial administration were also used to further strengthen the finding of the study.

\section{Finding}

Prior to the entry of British colonialism, the communication system was crucial to connecting one place to another regardless of the any ways or alternatives. A few years before the British colonialism era, the river has become the hub routes among the local community to get to the destination (Mohd Zamberi A. Malek, 2001). However, the growing economic activity from time to time has resulted in a traditional communication system were unable to accommodate the daily activities among the local communities for business purposes or daily routine. Based on this problem, Sir Frank Swettenham has proposed the construction of the first railway network in Perak.

\section{In a state having area of 10,000 square miles, where the only means of communication were river navigable from native boats and jungle path without bridges, it was natural that the first efforts of intelligent administration should be directed to the construction of roads and railways. ( Swettenham, F. A., 1893)}

The State of Perak is also the pioneer of the construction of the first railway route in the connecting route between Taiping and Port Weld. During the early development in Perak, railway network plays an important role as a transportation medium of tin ore to be melted in Penang (Mohd Hairy Ibrahim et al, 2014). Even the construction of a road network was also developed throughout the state of Perak which originally intended to transport tin ore mines. 
Thus, the Public Work Department has its own task in ensuring that these network connections were implemented according to the designated plans.

The construction of the first eight miles of railway is also said to be the most important construction works for the year. Based on the Perak Annual Report 1884, preliminary estimates of the cost of completing training routes, including locomotives and buildings are $\$ 8,000$ per stone and eight miles of mileage cost $\$ 357,000$ (Straits Settlement Annual Report, 1884). The construction of the route has made it the most expensive railway in Perak in the early stage of the British administration. The construction of the 13 kilometer railroad was started in 1882. The Port Weld-Taiping railway service has been the catalysts for increased in the production of tin and developed the economic activity (Amarjit Kaur, 1988). The opening of the railways was also influenced by the insistence of Chinese miners to fulfill their request to construct the railways near the mining sites. The transitional area of mining from Taiping to Ipoh also caused a change in the transportation system from Taiping to Ipoh.

Governor of the Straits Settlements, Sir Frederick Aloysius Weld had stated that there were no engineers who have sufficient expertise and experience to supervise the construction works (M. E. Wayte, 1959). In the early stages of its development, railway routes were monitored by the British administration because the early construction was the most important. (Amarjit Kaur, 1988). Port Weld also had experienced a transformation towards the development more comfortable living among the local communities.

Over the years, Port Weld has been listed as one of the leading and leading ports in Malaya (M. E. Wayte, 1959). For 15 months, it became the terminal for the train route in Perak. Port Weld has been proposed to continue providing the convenience of transport services from time to time and continuous improvements were carried out. The construction of the railway route has its main purpose, which is more for the development of the state, although its construction does not have large amounts of profits. The major construction work in 1897 includes the reclamation of lands as the addition to the completion of the 29-mile SiputEnggor River and plate installation as the stabilizer. The construction of the Perak River bridge began in November 1897 with 1185 feet long and used to be the longest bridge on the peninsula of Malaya and became one of the major construction. The elevation constructed has exceeded the level of flood water that usually hit the area.

At the end of 1897, another four new railway connections were approved. The route also connects the train station from Perak to the Prai station (M. E. Wayte, 1959). The Table 1 below shows the new railway route opened for traffic in Perak until 1903.

Table 1: The Railways Routes in Perak

\begin{tabular}{lcl}
\hline \multicolumn{1}{c}{ Route } & $\begin{array}{c}\text { Mileage } \\
\text { (miles) }\end{array}$ & Opening Date \\
\hline Taiping-Port Weld & 8 & 1 June 1885 \\
Taiping-Kamunting & 3 & 6 May 1890 \\
Kamunting-Ulu Sa'petang & 5 & 1 Julai 1892 \\
Telok Anson-Batu 16 & 16 & 19 May 1893 \\
Batu 16-Tapah Road & 1 & 6 September 1893 \\
Batu Gajah-Ipoh & 8 & 17 October 1893 \\
Kota Bharu-Batu Gajah & 5 & 27 April 1894 \\
Tapah Road-Talam & 7 & 29 September 1894 \\
Talam-Kampar & 2 & 18 Mac 1895 \\
Kampar-Kota Bharu & 8 & 1 May1895
\end{tabular}




\begin{tabular}{lcl} 
Ipoh-Tanjung Rambutan & 8 & 1 June 1896 \\
Tanjung Rambutan-Chemor & 4 & 27 November 1896 \\
Chemor-Sungai Siput & 7 & 5 July 1897 \\
Sungai Siput-Enggor & 7 & 1 July 1898 \\
Ulu Sa'petang- Pondok Tanjung & 3 & 1 September 1899 \\
Sungai Krian-Bagan Serai & 11 & 1 November1899 \\
Enggor-Kuala Kangsar & 5 & 15 September 1900 \\
Bagan Serai-Alor Pongsu & 4 & 1 May 1901 \\
Kuala Kangsar-Padang Rengas & 6 & 1 July 1901 \\
Alor Pongsu-Pondok Tanjung & 10 & 1 Febuary 1902 \\
Taiping-Bukit Gantang & 5 & 1 May 1902 \\
Tapah Road-Bidor & 7 & 1 May 1902 \\
Bukit Gantang-Padang Rengas & 7 & 15 July 1903 \\
Bidor-Sungkai & 8 & 15 July 1903 \\
Slim River-Tanjong Malim & 13 & 15 July 1903 \\
Sungkai-Slim River & 14 & 15 August 1903 \\
\hline
\end{tabular}

Sources: Annual Report on the Federated Malay States Railways 1907. Page 34

Based on Table 1, the construction of a railway or rail network in Perak was constructed in stages and opened in 1885 until 1903. Taiping train route to Port Weld was the first railway route opened in Perak on 1 June 1885 with a distance of 8 miles or 12.9 kilometers. The train route from Teluk Anson to Batu 16 was the longest distance i.e. 16 miles or equal to 25.7 kilometers and was opened on May 19, 1893.

In addition to the railway route, the construction of the road facility's system was also the focus of the Public Works Department in an effort to expand the communication network in the state of Perak. However, the importance of the road network construction was not comparable to the railway network and its construction does not involve high investment (Amarjit Kaur, 1980). At the beginning of the construction of the road network in the state of Perak, the difficulty encountered was to ensure that the road surface structure in good condition. However, this constraint does not hinder the construction of road structures throughout Perak states.

The construction of roads connecting Taiping and Kemunting was one of the earliest road routes built at the end of 1875 for six kilometer length (Khoo Kay Kim, 1991). The construction of the road was to facilitate the transport of tin ore at a nearby mining site. The British policy in the state of Perak has led to the increasing number of English people to Taiping town (Mohd Zamberi A. Malek, 2001). The English people who live in Taiping town are said to be superior in their ranks, classes and occupations including the comfort of their settlement. Therefore, the Public Works Department has played an important role in the development and conservation in the Maxwell Hill area. The increase in labor wages was resulted in increasing the transportation costs (Perak Secretariat 356/1948). This issue was encouraging the Public Work Department to find solutions by using horse riding services in the development process at Bukit Larut. Until 1947, road access to the Maxwell Hill was only 5.5 miles away (Amarjit Kaur, 1988). In order to ensure the maintenance work-saving process, a permanent drainage is constructed taking into account the high rainfall and land surface factors. Construction of the road facilities will shorten the duration of construction of residential houses and office buildings around the Maxwell Hill. The demand for bungalow construction also increased due to the factors of the development of transport infrastructure facilities by providing the Hill Jeep Services. 


\section{Conclusion}

Development in the state of Perak has been influenced by the relationship network structure which has encouraged various economic activities such as mining and agriculture. In fact, the establishment of Public Works Department has caused the road and railway network steadily increase to meet the needs of the industry as well as the convenience among the people of Perak. Establishment of the Public Works Department has contributed to the construction of railway and railway networks to facilitate the transport of tin ore. The Public Works Department has also introduced skills and expertise in engineering from Europe to encourage the development of a Western-oriented communications network.

\section{References}

Amarjit Kaur, 1988, Kereta Api di Perak, in Perak Dahulu dan Sekarang. Kuala Lumpur: Persatuan Muzium Malaysia.

Amarjit Kaur,1980, Road or Railways: Competition in Colonial Malaya 1909-1940, Journal of Malaysian Branch of Royal Asiatic Society, Vol 53 (2).

Annual Report on The State of Perak 1884

Khoo Kay Kim, 1991, Taiping (Larut): The Early History Of A Mining Settlement, Journal of the Malaysian Branch of the Royal Asiatic Society. Vol 64 (1)

Khoo Salma Nasution \& Abdur Razzaq Lubis, 2005, Kinta Valley Pioneering Malaysia's Modern Development. Ipoh: Perak Academy

Li, D.J., 1982, British Malaya, An Economic Analysis. Kuala Lumpur: Institut of Social Analysis.

M.E Wayte, 1959, Port Weld, Journal of Malayan Branch of the Royal Asiatic Society, Vol $32(1)$.

Mohd Hairy Ibrahim et al, Investigation of The Landscape Change in Old Malaysians Railway: Special Reference To Port Weld-Taiping Railway. Journal of Social Science, Vol 9 (5). Pg 357. 357-361

Mohd Zamberi A. Malek, 2001, Larut Daerah Terkaya. Bangi:Penerbit Universiti Kebangsaan Malaysia.

Moo, H. P. \& Fernando J.M., 2018, The Role of Public Work Department in The Development And Administration Of Waterwork In Kuala Lumpur 1900-1941. Jurnal Sejarah, Vol 27 (1). 26-42

Perak Secretariat 439/1948, Public Work Department, Perak Annual Report for 1947

Perak Secretariat, 356/1948, Hill Garden, Maxwell Hill Taiping

Proceeding of Federal Malay State For The Year 1933

R.S Nathan,1970, Development of District Administration in Batang Padang in Malaysia in History. Vol 13 (1).

Swettenham, F. A., 1893, About Perak. Singapore: Straits Times Press 